\title{
Emerging Non-Thermal Technologies for the Extraction of Grape Anthocyanins
}

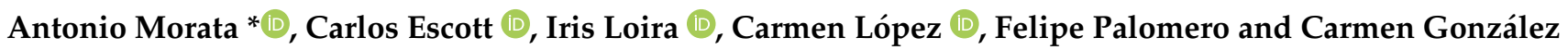 \\ enotecUPM, Chemistry and Food Technology Department, Technical University of Madrid UPM, \\ 28040 Madrid, Spain; carlos.escott@gmail.com (C.E.); iris.loira@upm.es (I.L.); carmen.lopez@upm.es (C.L.); \\ felipe.palomero@upm.es (F.P.); carmen.gchamorro@upm.es (C.G.) \\ * Correspondence: antonio.morata@upm.es
}

Citation: Morata, A.; Escott, C.; Loira, I.; López, C.; Palomero, F.; González, C. Emerging Non-Thermal Technologies for the Extraction of Grape Anthocyanins. Antioxidants 2021, 10, 1863. https://doi.org/ 10.3390/antiox10121863

Academic Editors: Agustín G. Asuero and Noelia Tena

Received: 2 November 2021

Accepted: 22 November 2021

Published: 23 November 2021

Publisher's Note: MDPI stays neutral with regard to jurisdictional claims in published maps and institutional affiliations.

Copyright: (c) 2021 by the authors. Licensee MDPI, Basel, Switzerland. This article is an open access article distributed under the terms and conditions of the Creative Commons Attribution (CC BY) license (https:/ / creativecommons.org/licenses/by/ $4.0 /)$.
Abstract: Anthocyanins are flavonoid pigments broadly distributed in plants with great potential to be used as food colorants due to their range of colors, innocuous nature, and positive impact on human health. However, these molecules are unstable and affected by $\mathrm{pH}$ changes, oxidation and high temperatures, making it very important to extract them using gentle non-thermal technologies. The use of emerging non-thermal techniques such as High Hydrostatic Pressure (HHP), Ultra High Pressure Homogenization (UHPH), Pulsed Electric Fields (PEFs), Ultrasound (US), irradiation, and Pulsed Light (PL) is currently increasing for many applications in food technology. This article reviews their application, features, advantages and drawbacks in the extraction of anthocyanins from grapes. It shows how extraction can be significantly increased with many of these techniques, while decreasing extraction times and maintaining antioxidant capacity.

Keywords: non-thermal technologies; grapes; wine; anthocyanins; HHP; UHPH; PEFs; US; irradiation

\section{Introduction}

Anthocyanins are flavonoid pigments responsible for the color of many fruits, flowers and vegetable tissues. Extensive details on their properties and features can be found in the literature [1-9]. They have been extensively studied for their potential applications as natural colorants [10-12] as they are innocuous and safe molecules, but also for their positive impact on health due to their antioxidant properties $[13,14]$ and their effect on the gut microbiome [15]. Anthocyanin color depends on the substitution pattern in the B-ring and the acylation patterns, both of which affect the electron density and the observed color, ranging in grapes from red orange (brownish red) to bluish red (purple), with typical ranges from $518 \mathrm{~nm}$ of maximum absorption for cyanidin to $528 \mathrm{~nm}$ for malvidin [16]. Acylation normally increases the maximum absorption (e.g., malvidin $528 \mathrm{~nm}$ to coumaroyl malvidin $535 \mathrm{~nm}$ ) (Table 1). The color of anthocyanins is also affected by low $\mathrm{pH}$, which increases the color intensity by the hyperchromic effect, shifting the equilibria to increase the amount of pyrilium cation. Additionally, anthocyanins can also undergo $\mathrm{SO}_{2}$ bleaching and co-pigmentation processes that produce bluish red pigments by bathochromic shifts in the maximum wavelength of absorbance [16].

In most grape varieties, anthocyanins are located in the exocarp (skins) (Figure 1A,B), which are the layers of cells in the outer surface of the berry; only a few varieties also have anthocyanins in the pulp [16]. The skins have a thicker cell wall than the pulp to protect the berry mechanically and against rot and pests. 
Table 1. Molecular structure, substitution pattern in the B-ring (R1 and R2), acylation patterns (R3), maximum $\lambda$ (nm), and color of grape's anthocyanins.

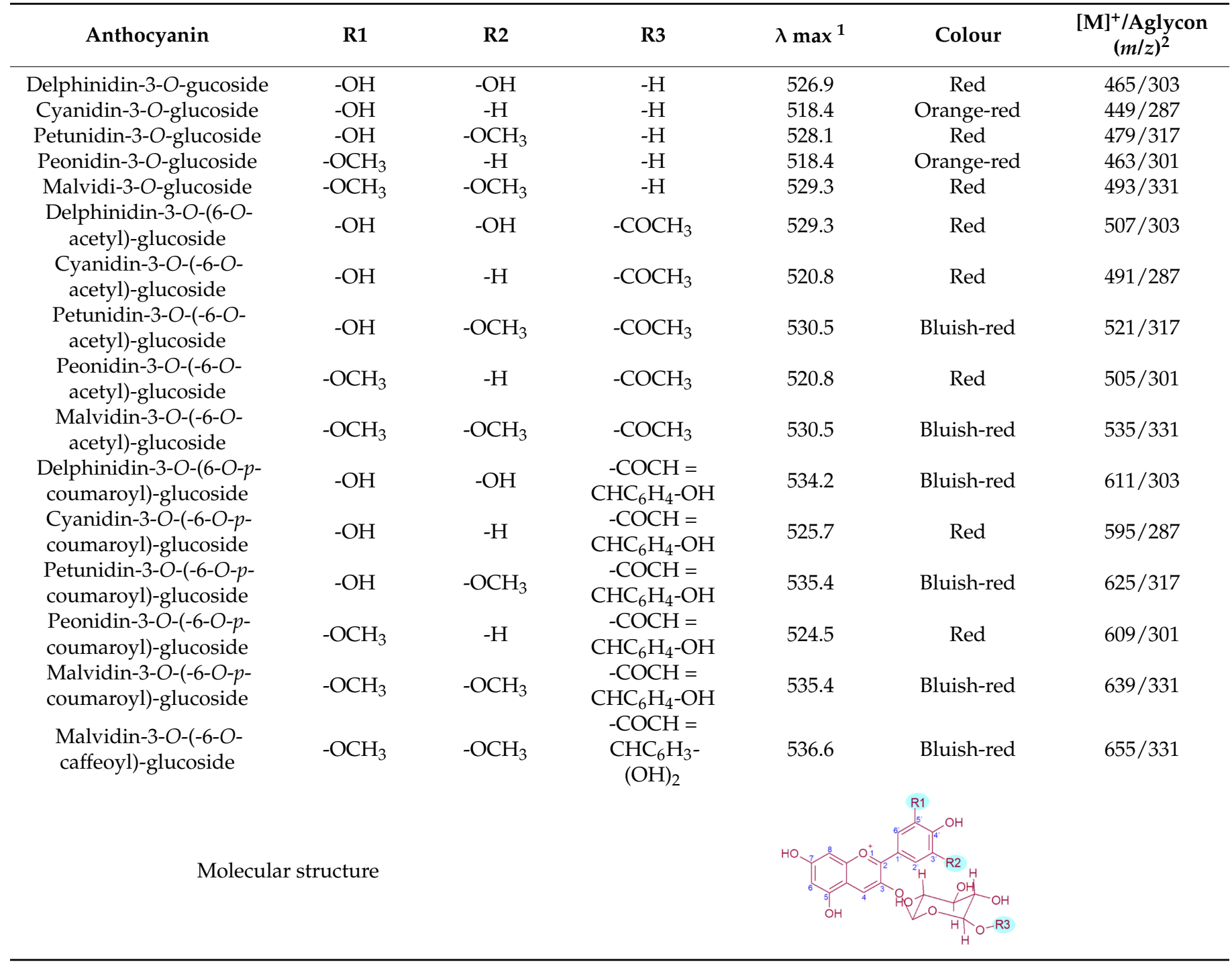

${ }^{1}$ Obtained experimentally with HPLC-DAD-ESI/MS; ${ }^{2}$ From [17].
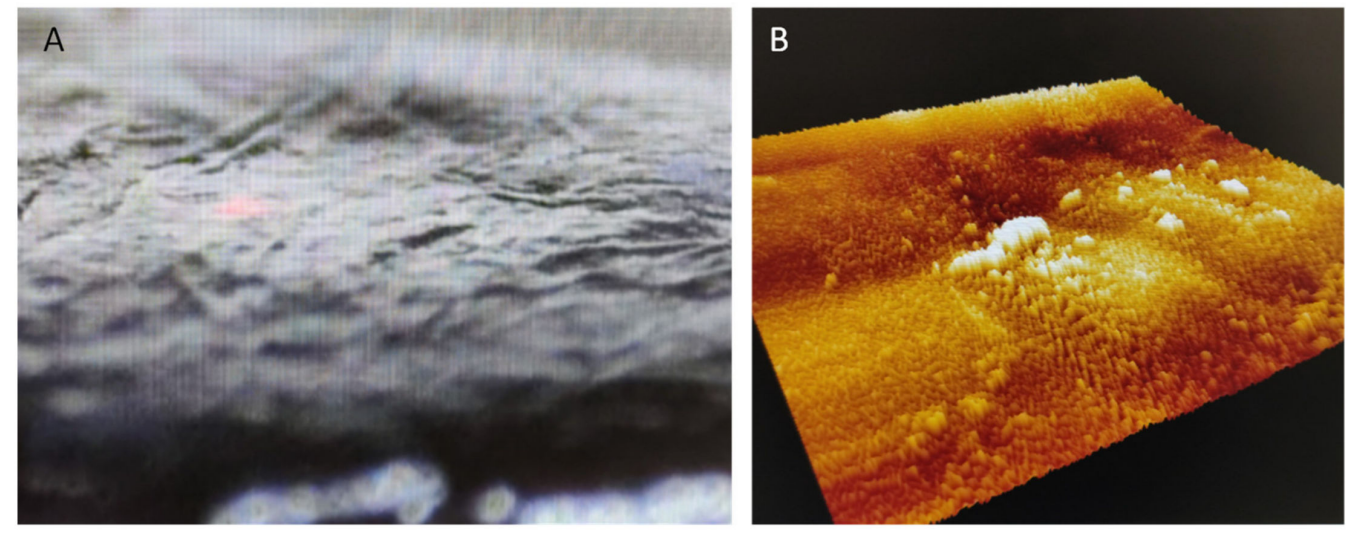

Figure 1. (A) Red grape skin (exocarp) Vitis vinifera L. Tempranillo variety by $60 \mu \mathrm{m}$ optical camera built-in part of the AFM. (B) 3D Topography of the same skin by atomic force microscopy.

The structure and shape of the cells in the berries are flat cells in the skin and large polyhedral cells in the pulp (Figure 2A). Anthocyanins are located in the cells of the skin, 
inside the vacuole (Figure 2B). To extract the anthocyanins and to keep enough color (not only in red winemaking, but also in red juice production), it is necessary to disaggregate the cell wall polysaccharides, mainly the pectins (Figure 2C). In conventional winemaking, depolymerization of the cell wall and separation of polysaccharide fibers is achieved during maceration by means of soaking, fermentation temperature and mechanical treatments (i.e., punch downs, pump overs, délestage) [18].

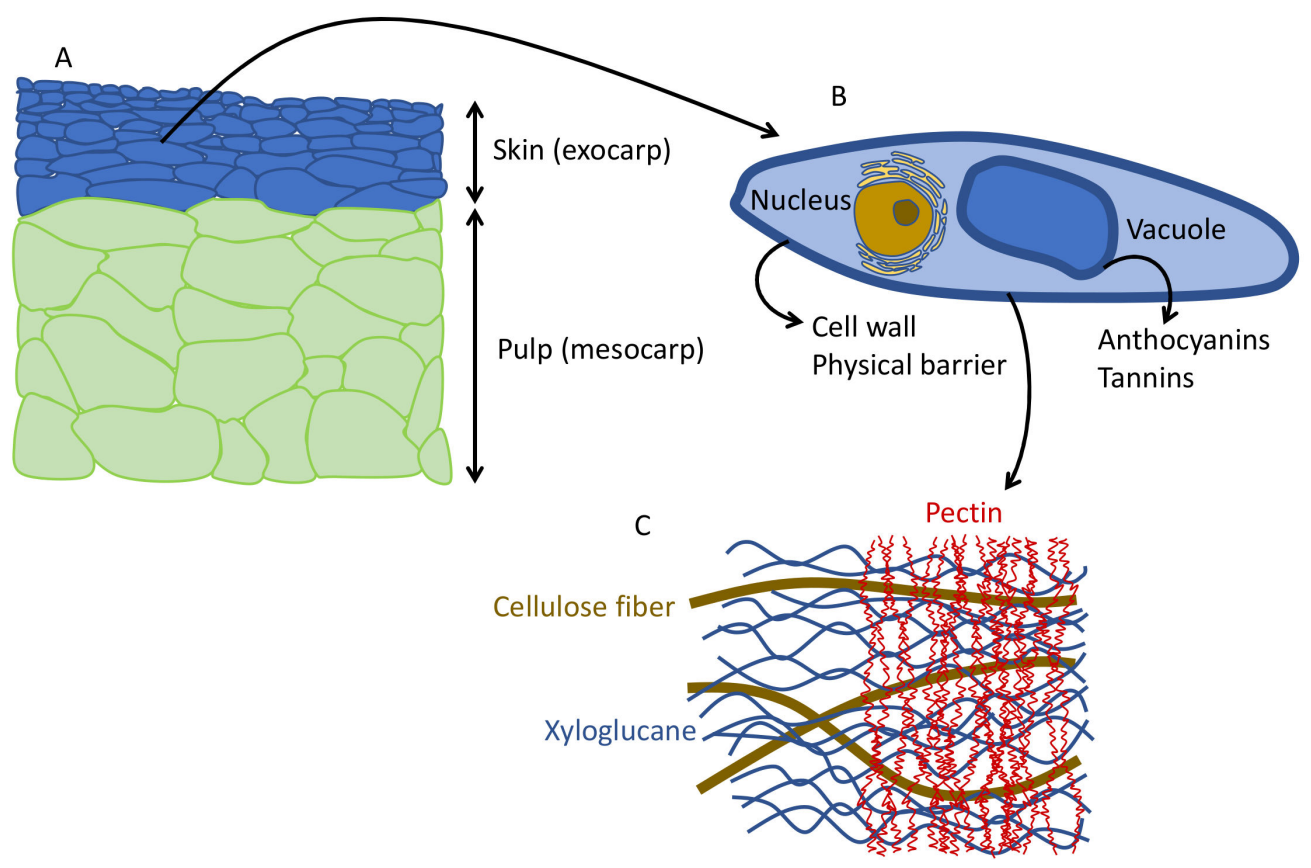

Figure 2. (A) Red grape section with flat colored cells in the skins and polyhedral cells in the pulp. (B) Skin cells shape and structure. (C) Cell wall fiber components.

In addition, cryomacerations (cold soak) by heat exchanger cooling or dry ice can be used to preferentially extract anthocyanins and aroma compounds in the absence of fermentation [19]. This is advantageous because it reduces the extraction of tannins whose solubility is lower in the absence of alcohol and better reduces astringency in young wines and juices. Another powerful technology to quickly degrade cell wall pectins and promote the extraction of anthocyanins, tannins and aroma compounds is the use of pectolytic enzymes [20], especially endo-polygalacturonases that break the pectin sequence depolymerizing the cell wall and releasing the pigments in the juice.

Currently emerging non-thermal technologies are increasingly being used to improve the extraction of bioactive compounds, such as anthocyanins, from food products, but also to decrease or eliminate spoilage or pathogenic microorganisms and sometimes even to inactivate oxidative enzymes [21,22]. Among them, continuous and discontinuous high-pressure technologies (i.e., High Hydrostatic Pressure (HHP) and Ultra High Pressure Homogenization (UHPH) [23-25], Pulsed Electric Fields (PEFs) [26-29], Ultrasound (US) [30-34] and $\beta$-irradiation [35-37].

This review is focused on the features of emerging non-thermal technologies that make them suitable for the extraction of anthocyanins from grape skins while protecting their natural coloring and antioxidant properties.

\section{Use of High-Pressure Technologies to Extract Anthocyanins}

The use of high-pressure technologies is growing exponentially in the food industry. A PubMed search using the keywords high, pressure and food yields 40,077 research articles in the period 1970-2021 with 36,920 since 2000. Although several technologies can be found, research with continuous (Ultra)-High Pressure Homogenization processes (UHPH and $\mathrm{HPH}$ ) and discontinuous High Hydrostatic Pressure (HHP) technologies stand out. All 
of them share gentle food processing as they are non-thermal treatments with low impact on food quality, sensory constituents and nutraceutical components [25,38-41]. HHP and UHPH technologies are industrially implemented and several brands compete in the market. In batch technologies, the leading companies are Hiperbaric (https:/ /www.hiperbaric. com/es/ (accessed on 2 November 2021)) and Avure (https:/ / www.jbtc.com/es/northamerica/foodtech/products-and-solutions/brands/avure-technologies (accessed on 2 November 2021)). In UHPH (continuous processing), the most effective technology is the one developed by Ypsicon (https:/ / www.ypsicon.com/ (accessed on 2 November 2021)). These technologies have specific characteristics that will be described separately below.

\subsection{High Hydrostatic Pressure (HHP)}

HHP involves the application of high pressures to the food by means of a fluid (hydrostatic), which is usually water. The fluid is pumped into a high-strength steel vessel containing the food product, where pressures above $100 \mathrm{MPa}$, commonly in the range of 400-600 MPa, are reached during processing [42]. HHP treatments consist of pressurizing the food product in this pressure range for $2-10 \mathrm{~min}$. The main effect of this is the destruction of the cell walls and membranes of microorganisms, but plant and animal tissue cells are also similarly affected. HHP can be considered a non-thermal technology because, even when compression produces adiabatic heating, this is quite moderate and ranges between 2 and $3{ }^{\circ} \mathrm{C} / 100 \mathrm{MPa}$. This slight increase in temperature can be controlled by cooling the vessel or lowering the temperature of the food at the inlet. Moreover, HHP processing is not able to affect covalent bonds, so pigments, aroma and flavors are usually protected $[24,38,42]$.

The effect of HHP on plant tissues is to damage the integrity of the cell walls, resulting in small pores or fissures that can facilitate the extraction of metabolites from the cell wall. HHP has been used to enhance the extraction of anthocyanins from grapes $[23,24]$ and grape pomace [26]. The extraction of anthocyanins by HHP has been increased compared to controls in the range of $23-82 \%$ (Table 2). The extraction of phenolic compounds (tannins) is also increased in grapes, with a total polyphenol index of $+26 \%$ [24], and the antioxidant activity of the extracts is higher than in controls [23,26]. HHP is a powerful technology to extract anthocyanins from plant tissues, and specifically from grape skin, preserving or enhancing the antioxidant capacity of the extracts, working at low temperatures $\left(<30^{\circ} \mathrm{C}\right.$, at $550 \mathrm{MPa}$ for $10 \mathrm{~min}$ [24]), even under refrigeration. Furthermore, anthocyanin extraction has been reported to be selective depending on the acylation pattern and the methoxilation ratio on the $B$ ring [23]. In grapes, anthocyanin migration from the skin to the pulp and seeds is observed after HHP treatment (Figure 3), which is evidence of cell wall poration and anthocyanin migration into the berry under the effect of pressure [24]. HHP causes the intensification of mass transfer phenomena, thus affecting cell permeability and molecule diffusion [43]. However, the external shape and structure of the berry are completely preserved (Figure 3). It is noticeable that similar extractions can be achieved in the range of 200-550 MPa, so it is possible to use milder HHP conditions, making the process cheaper while working at lower temperatures by adiabatic compression. Lower temperatures help to protect the anthocyanins during extraction and later in the ongoing process [44], probably reducing the risk of oxidation that can occur under thermal conditions.

The processing of grapes by HHP can be done with whole grapes (Figure 3), but it is also possible to process the separated skins that can be obtained from by-products such as pomace. Additionally, the stability of anthocyanins can be improved by using additives such as ethanol or other preservatives. HHP processing of berries also helps to sanitize them by easily removing yeasts and highly reducing bacterial loads [21,24]. This helps to obtain healthier anthocyanin extracts with reduced microbial loads, which facilitates the implantation of starters if these extracts are subsequently used in fermented foods [45]. Additionally, gentle extraction together with inactivation of microorganisms and higher antioxidant activity can reduce the use of antioxidants such as sulfites in the extracts, and also in the subsequent use of these extracts in food products [21,46]. 


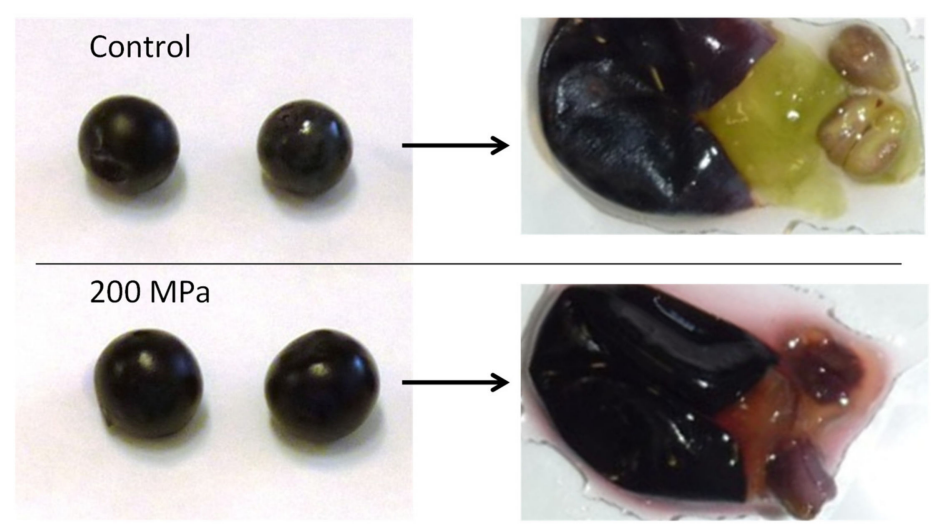

Figure 3. External shape and appearance of control and pressurized grapes (200 MPa, $10 \mathrm{~min}$ ), and details of the internal structure showing colored pulp and seeds in HHP-processed grapes.

Table 2. Emerging non-thermal technologies, processing conditions, and effects on the extraction of anthocyanin.

\begin{tabular}{|c|c|c|c|c|c|}
\hline $\begin{array}{l}\text { Emerging } \\
\text { Non-Thermal } \\
\text { Technology }\end{array}$ & $\begin{array}{l}\text { Processing } \\
\text { Mode }\end{array}$ & Product/Conditions & Effect & $\begin{array}{l}\text { Extraction of } \\
\text { Anthocyanins }\end{array}$ & Reference \\
\hline \multirow{3}{*}{ HHP } & Discontinuous & $\begin{array}{c}\text { Grape skins } \\
70^{\circ} \mathrm{C}, 600 \mathrm{MPa}\end{array}$ & $\begin{array}{c}\uparrow \text { extraction } \\
\uparrow \text { antioxidant activity }\end{array}$ & $+23 \%$ & [23] \\
\hline & & $\begin{array}{c}\text { Grapes } \\
<30^{\circ} \mathrm{C}, 200-550 \mathrm{MPa}, 10 \mathrm{~min}\end{array}$ & $\begin{array}{l}\text { } \text { extraction } \\
\text { Migration of } \\
\text { anthocyanins to pulp } \\
\text { and seeds }\end{array}$ & $+80 \%$ & [24] \\
\hline & & $\begin{array}{l}\text { Grape by-products } \\
70^{\circ} \mathrm{C}, 600 \mathrm{MPa}\end{array}$ & $\begin{array}{c}\uparrow \text { extraction } \\
\text { Phenols }+50 \% \\
\uparrow \text { antioxidant activity } \times 3\end{array}$ & $+41 \%$ & [26] \\
\hline UHPH & Continuous & $\begin{array}{c}\text { Grape juice } \\
300 \mathrm{MPa}, 78{ }^{\circ} \mathrm{C},<0.2 \mathrm{~s}\end{array}$ & $\begin{array}{c}\uparrow \text { extraction } \\
\uparrow \text { antioxidant activity }\end{array}$ & $+2.6 \%$ & [47] \\
\hline \multirow{7}{*}{ PEF } & Continuous & $\begin{array}{c}\text { Grapes } \\
3 \mathrm{kV} / \mathrm{cm}, 50 \text { pulses }\end{array}$ & $\begin{array}{c}\uparrow \text { extraction } \\
\uparrow \text { juice yield }+5 \%\end{array}$ & $\times 3$ & [48] \\
\hline & Discontinuous & $\begin{array}{c}\text { Grape by-products } \\
\text { Exponential decay pulses, } 70^{\circ} \mathrm{C}, \\
30 \mathrm{kV} / \mathrm{cm}, 10 \mathrm{~kJ} / \mathrm{kg}, 30 \text { pulses, } 2 \mathrm{~Hz} \text {, } \\
15 \mathrm{~s}\end{array}$ & $\begin{array}{c}\text { Textraction } \\
\text { Phenols }+50 \% \\
\uparrow \text { antioxidant activity } \times 4\end{array}$ & $+77 \%$ & [26] \\
\hline & Discontinuous & $\begin{array}{c}\text { Mazuelo grapes } \\
\text { Exponential decay pulses, }<30^{\circ} \mathrm{C}, 2,5 \\
\text { and } 10 \mathrm{kV} / \mathrm{cm}, 0.4,1.8 \text {, and } 6.7 \mathrm{~kJ} / \mathrm{kg}, \\
50 \text { pulses, } 1 \mathrm{~Hz}\end{array}$ & $\begin{array}{c}\uparrow \text { extraction } \\
\text { Phenols }+20-31 \%\end{array}$ & $\begin{array}{c}+20.3,28.6 \text { and } \\
41.8 \% \text { after } 120 \mathrm{~h}\end{array}$ & [49] \\
\hline & Discontinuous & $\begin{array}{c}\text { Pinot noir grapes } \\
\text { Square wave bipolar pulses, } 1.5 \mathrm{kV} / \mathrm{cm} \text {, } \\
15 \text { and } 70 \mathrm{~kJ} / \mathrm{kg}, 50 \mathrm{~Hz} \text {, pulse width of } \\
20 \mu \mathrm{s} \text {, pulse numbers of } 243 \text { and } 1033\end{array}$ & $\begin{array}{c}\text { Textraction } \\
\uparrow \text { Phenols } \\
\uparrow \text { bioprotective capacity }\end{array}$ & $\begin{array}{c}+43-74 \% \text { after } \\
2 \text { days }\end{array}$ & [50] \\
\hline & Continuous & $\begin{array}{c}\text { Cabernet sauvignon grapes } \\
\text { Square pulses, width of } 3 \mu \mathrm{s} \text {, collinear } \\
\text { chamber, } 2,5 \text { and } 7 \mathrm{kV} / \mathrm{cm} ; 0.56,3.67 \\
6.76 \mathrm{~kJ} / \mathrm{kg},<23^{\circ} \mathrm{C}, 50 \text { pulses, } 122 \mathrm{~Hz} \\
\text { Flow } 118 \mathrm{~kg} / \mathrm{h} \text {. Average residence time } \\
0.41 \mathrm{~s}\end{array}$ & $\begin{array}{c}\uparrow \text { extraction } \\
\text { Phenols }+14-36 \%\end{array}$ & $\begin{array}{c}+18-45 \% \text { after } \\
24 \mathrm{~h}\end{array}$ & [51] \\
\hline & Continuous & $\begin{array}{c}\text { Garnacha grapes } \\
\text { Square pulses, width of } 3 \mu \mathrm{s} \text {, collinear } \\
\text { chamber, } 4.3 \mathrm{kV} / \mathrm{cm}, 60 \mu \mathrm{s} \\
\text { Flow } 1900 \mathrm{~kg} / \mathrm{h} \text {. Average residence time } \\
0.41 \mathrm{~s}\end{array}$ & $\begin{array}{c}\uparrow \text { extraction } \\
\text { Phenols }+23 \%\end{array}$ & $+25 \%$ after 7 days & [52] \\
\hline & Continuous & $\begin{array}{c}\text { Merlot grapes } \\
>30 \mathrm{kV} / \mathrm{cm}, 4.7-49.4 \mathrm{~kJ} / \mathrm{L} \\
\text { Flow } 500 \mathrm{~kg} / \mathrm{h}\end{array}$ & $\begin{array}{c}\uparrow \text { extraction } \\
\uparrow \text { Phenols }+23-162 \% \\
\text { Shortening of cold } \\
\text { macerations }\end{array}$ & $\begin{array}{c}+17-636 \% \text { after } \\
24 \mathrm{~h}\end{array}$ & [53] \\
\hline
\end{tabular}


Table 2. Cont.

\begin{tabular}{|c|c|c|c|c|c|}
\hline $\begin{array}{l}\text { Emerging } \\
\text { Non-Thermal } \\
\text { Technology }\end{array}$ & $\begin{array}{l}\text { Processing } \\
\text { Mode }\end{array}$ & Product/Conditions & Effect & $\begin{array}{l}\text { Extraction of } \\
\text { Anthocyanins }\end{array}$ & Reference \\
\hline & Continuous & $\begin{array}{c}\text { Rondinella grapes } \\
\text { Square-wave pulses at } 1.5 \mathrm{kV} / \mathrm{cm}, 1,5 \\
\text { and } 10 \mu \mathrm{s}, 2,10 \text { and } 20 \mathrm{~kJ} / \mathrm{kg}, 400 \mathrm{~Hz} \\
\text { Flow } 250 \mathrm{~L} / \mathrm{h}\end{array}$ & $\begin{array}{c}\uparrow \text { extraction } \\
\uparrow \text { Phenols }+37 \%\end{array}$ & $\begin{array}{l}+30 \% \text { color } \\
\text { intensity after } \\
\text { fermentation }\end{array}$ & [54] \\
\hline & Continuous & $\begin{array}{c}\text { Grenache grapes } \\
\text { Pulses of } 5 \mathrm{kV} / \mathrm{cm}, 63.4 \mathrm{~kJ} / \mathrm{kg} .1800 \mu \mathrm{S} \\
(45 \text { pulses of } 40 \mu \mathrm{S}) \text { Average residence } \\
\text { time } 0.38 \mathrm{~s} \text {. Temperature }<32 \pm 2 \\
\text { Flow } 120 \mathrm{~kg} / \mathrm{h}\end{array}$ & $\begin{array}{c}\uparrow \text { extraction } \\
\uparrow \text { Phenols } \times 1.6\end{array}$ & $\times 2.2$ after $24 \mathrm{~h}$ & {$[55]$} \\
\hline \multirow{5}{*}{ Ultrasounds } & Discontinuous & $\begin{array}{l}\text { Tannat grape pomace. US bath: } \\
15-60{ }^{\circ} \mathrm{C}, 0-100 \mathrm{~W}, 5-50 \mathrm{~min}\end{array}$ & $\begin{array}{c}\uparrow \text { extraction } \\
\uparrow \text { Phenols }+50 \%\end{array}$ & $+50 \%$ & {$[56]$} \\
\hline & Discontinuous & $\begin{array}{c}\text { Red grape pomace US bath: } \\
25^{\circ} \mathrm{C}, 160 \mathrm{~W}, 40 \mathrm{kHz}, 30 \mathrm{~min}, 0.4 \mathrm{~W} / \mathrm{mL}, \\
720 \mathrm{~J} / \mathrm{mL}\end{array}$ & 个extraction & $+59 \%$ after $5 \mathrm{~min}$ & [33] \\
\hline & Discontinuous & $\begin{array}{c}\text { Monastrell grapes } \\
\text { US bath: } 18^{\circ} \mathrm{C}, 40 \mathrm{kHz}, 280 \mathrm{~W}, 90 \mathrm{~min}\end{array}$ & $\begin{array}{c}\uparrow \text { extraction } \\
\uparrow \text { Phenols +9\% }\end{array}$ & $\begin{array}{l}+8 \% \text { first day of } \\
\text { maceration }\end{array}$ & [57] \\
\hline & Discontinuous & $\begin{array}{c}\text { Wine lees } \\
\text { Sonifier Cell Disruptor Model 450, high } \\
\text { gain horn of } \frac{3}{4} \text { " of diameter. Time of } \\
\text { sonication } 30-90 \mathrm{~s}\end{array}$ & $\begin{array}{l}\text { ₹extraction } \\
\text { Lower time }\end{array}$ & $\begin{array}{l}33 \% \text { of the } \\
\text { control time }\end{array}$ & {$[58]$} \\
\hline & Discontinuous & $\begin{array}{l}\text { Grape pomace Moldova variety } \\
\text { ultrasonic transducer coupled with a } \\
\text { function generator }\end{array}$ & 个extraction & $\begin{array}{l}+18 \% \text { from } 12.5 \\
\quad \text { to } 25 \mathrm{kHz}\end{array}$ & [59] \\
\hline$\beta$-irradiation & Continuous & $\begin{array}{c}\text { Tempranillo grapes } \\
\text { 10-MeV, 50-kW Rhodotron accelerator, } \\
\text { scan frequency of } 100 \mathrm{~Hz} \\
\text { oses of } 0 \text { (control), } 0.5,1 \text { and } 10 \mathrm{kGy}\end{array}$ & 个extraction & $+71 \%$ at $10 \mathrm{kGy}$ & [37] \\
\hline
\end{tabular}

\subsection{Ultra High Pressure Homogenization (UHPH)}

UHPH consists of the continuous pressurization of a fluid to $200 \mathrm{MPa}$ or more, through a special valve, and its subsequent release at low pressure (usually atmospheric pressure) $[25,41,60,61]$. Typical processing conditions are the use of $300 \mathrm{MPa}$ with valve residence times less than $0.2 \mathrm{~s}$. The process can be heat-assisted by using upstream heat exchangers, which greatly increases efficiency. The short processing time, even when high temperatures are used in the valve, produces a very gentle treatment with high nutritional and sensory quality [25]. The preservation of antioxidant activity [62], the control of oxidative enzymes such as polyphenol oxidases (PPOs) [62-64], the preservation of delicate aromatic molecules such as terpenes [64], and the absence of thermal markers have been observed in the processing of grape juices by UHPH [64].

The UHPH process and the passing through the valve produce high impact forces and intense shear stresses, and the result is a significant nanofragmentation of plant tissues with removal of microorganisms, including spores depending on the temperature in the valve, inactivation of enzymes and nanofragmentation of colloidal particles. The consequence is increased extraction by cell disruption and improved bioaccessibility [65]. The mechanical effect is highly dependent on the valve design, and the antimicrobial effect with mild impact on the residence time and the design of the heat exchangers upstream and downstream of the valve [25] (Figure 4). One of the most effective designs is the one developed by Ypsicon [66].

There is a size requirement concerning the maximum size of colloidal particles in the grape juice before pressurization due to the cross-sections in the fluidic components of the pump and valve. Particles in the fluid should be less than $500 \mu \mathrm{m}$ to avoid clogging (Figure 4) [25]. After the treatment, the particles are fragmented in the range of $100-500 \mathrm{~nm}[25,64]$. When grape juice, which has many colloidal constituents with a poly- 
hedral appearance (Figure 5A), is processed by UHPH, a finer structure can be observed (Figure 5B) without large fragments [47].

\section{YPSICON valve $\mathrm{P}>300 \mathrm{MPa}$}

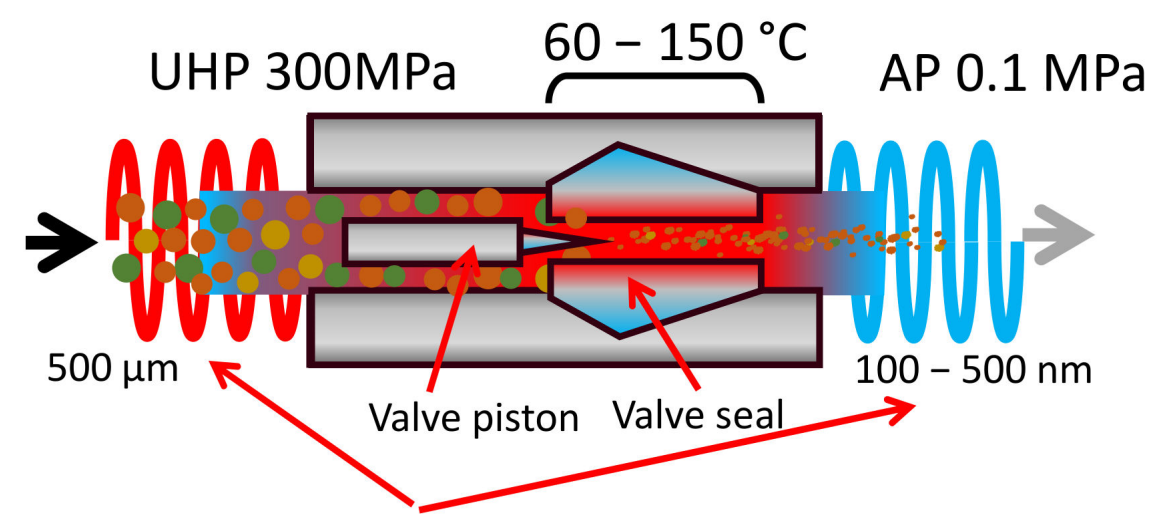

\section{Heat exchangers}

Figure 4. Scheme of the structure and components of a UHPH-Ypsicon valve. Intense impact and shear stresses together with the help of heating produce: pasteurization/sterilization, nanofragmentation, enzyme inactivation, nano-coating and nano-encapsulation.

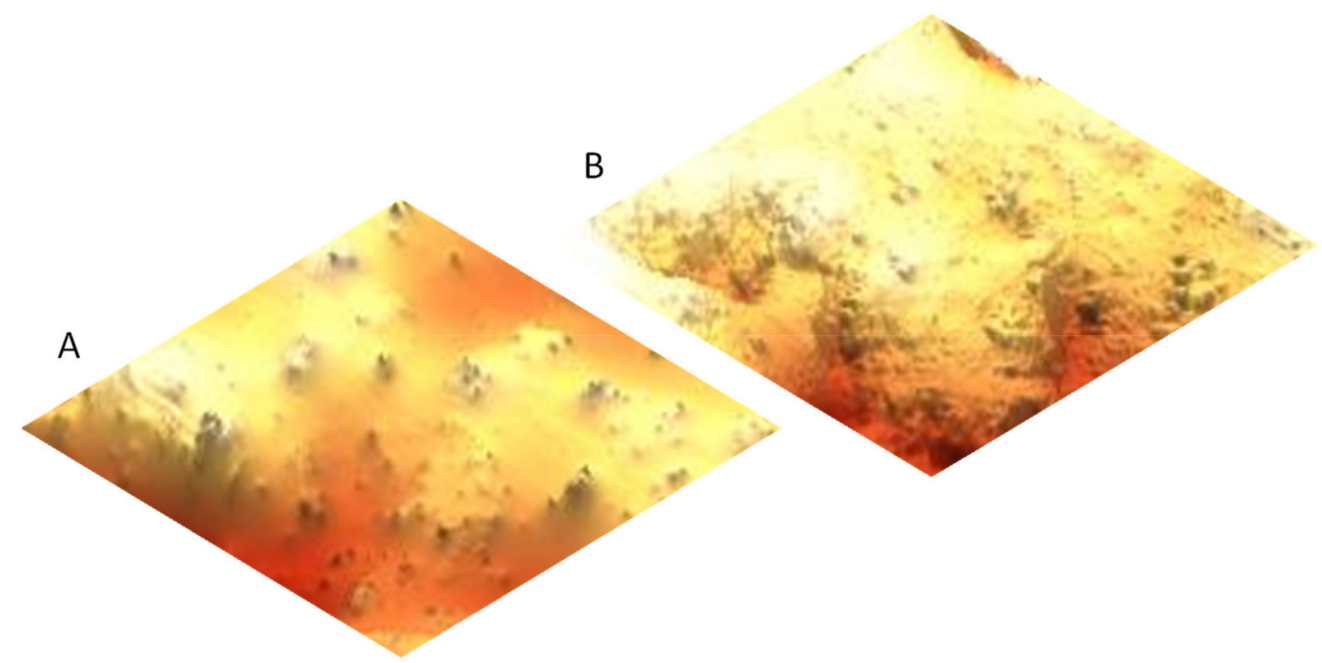

Figure 5. (A) Atomic Force Microscopy (AFM) topography of the surface of a dried red grape juice showing polyhedral granules, which are the colloidal particles of the juice (i.e., plant cell fragments and fibers). (B) The same dried red grape juice by AFM after UHPH treatment, with smaller granules and a flatter surface (no large polyhedral granules).

\section{Pulsed Electric Fields (PEFs) in the Extraction of Anthocyanins}

Like the previous ones (HHP and UHPH), PEFs have become a global technology with numerous applications in food processing, preservation and stabilization [67-71]. PEF is based on the use of high intensity electric fields $(3-40 \mathrm{kV} / \mathrm{cm})$ for a very short time (milli-micro seconds). Food is processed by PEF when it passes through two electrodes. The Electric Field Strength $(\mathrm{E})$ is the voltage $(\mathrm{kV})$ divided by the distance between the electrodes $(\mathrm{cm})$, i.e., $\mathrm{E}=\mathrm{V} / \mathrm{d}$. PEF systems are currently available on an industrial scale for food processing in the range of 50-10,000 L/ $\mathrm{h}$ for fluids and 1-70 tonnes $/ \mathrm{h}$ for solids such as French fries. The effect of PEFs is the poration of cells at the nanoscale, which affects the selective permeability [72]. These pores are difficult to observe by electronic microscopy. However, the pores produce various effects depending on size and number, 
tending to increase cell permeability, thus facilitating the extraction of cell compounds (e.g., anthocyanins and many others), the entry of compounds and the temporal or definitive inactivation of cells depending on the intensity [73]. Pulses can be applied in several modalities. The main parameters are the pulse shape (i.e., squared, exponential, sinusoidal), the polarity (i.e., monopolar or bipolar), the number of pulses and the pulse duration (Figure 6). The intensity and effectiveness of the treatments depend on the above parameters with squared bipolar pulses being more effective and the number of pulses making the process more powerful. Even when the pulse duration also improves the efficacy, it should be kept at a low value because it affects the temperature of the food by ohmic heating.
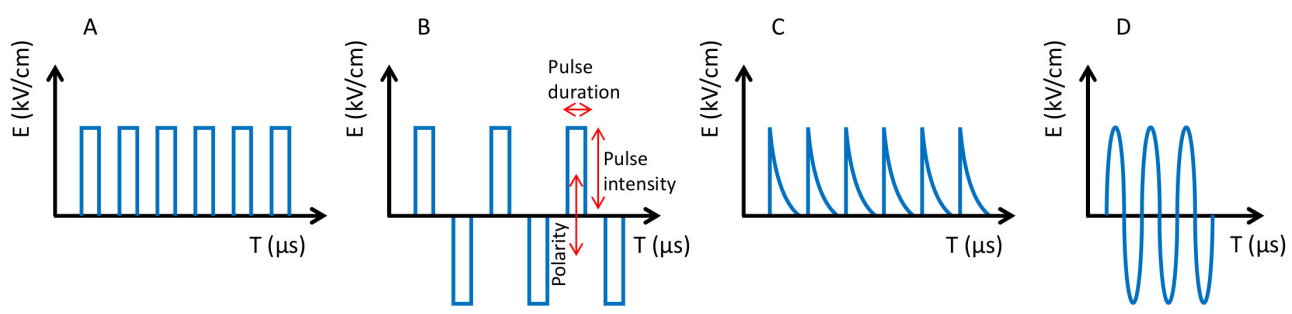

Figure 6. Types of pulses. (A) Squared monopolar. (B) Squared bipolar. (C) Exponentially decaying. (D) Sinusoidal.

Plant cells need lower intensities than microorganisms, especially bacteria, depending on size and shape. To induce permeabilization in plant cells (size 40-200 $\mu \mathrm{m}$ ), E must be 1-2 kV/cm, while in microorganisms (size 1-10 $\mu \mathrm{m}$ ), 12-20 kV/cm are required [74]. Therefore, to extract bioactive molecules from vegetal tissues, less than $5 \mathrm{kV} / \mathrm{cm}$ is necessary, however, for microbial inactivation, E should normally be higher than $10 \mathrm{kV} / \mathrm{cm}$. When plant cells are pored (i.e., grape skins), the consequence is an increased extraction of biomolecules such as anthocyanins, tannins and aroma compounds (Figure 7).

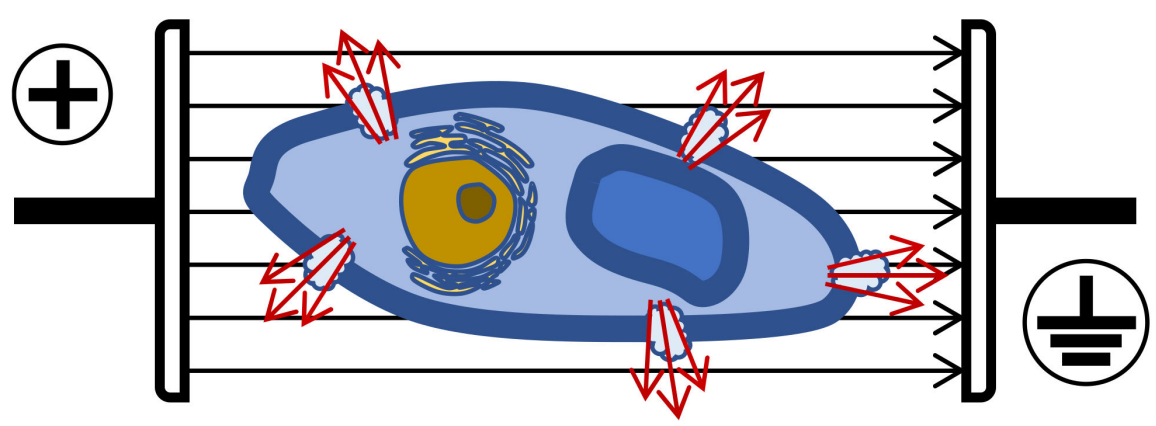

Figure 7. Electroporation and cell permeabilization.

At pilot and industrial scale, several works have demonstrated the efficiency of PEFs to increase the extraction of anthocyanins, and other phenols at low temperature while preserving their antioxidant capacity (Table 1). Currently grapes or by-products (grape pomace) can be processed continuously at a flow rate of several hundreds to a few tonnes of $\mathrm{kg}$ per hour (118 kg/h, [51]; $500 \mathrm{~kg} / \mathrm{h}$ [53], $1900 \mathrm{~kg} / \mathrm{h}$ [52]). Usually, the crushed gape is pumped by a progressive cavity pump [51] or a peristaltic pump [52] and later processed in a collinear chamber by applying exponentially decay pulses or, more frequently, squared pulses of an electric field strength ranging from 2 to $10 \mathrm{kV} / \mathrm{cm}[26,28,48,49,52,53]$. Anthocyanin extraction increases in the range of 17-100\% (Table 1) depending on processing conditions and post-maceration time. The temperature is increased by only $2-15{ }^{\circ} \mathrm{C}$ [55], therefore it is easy to work at room temperature or under refrigerated conditions. In addition to improved anthocyanin and phenol extraction, PEFs can be used for gentle nonthermal pasteurization of the must, thus improving the implantation of non-Saccharomyces starters [55] and potentially reducing the use of $\mathrm{SO}_{2}$. The effect of PEFs on the extraction 
of phenolic compounds from seeds has also been reported and should be considered in winemaking processes $[75,76]$.

\section{Ultrasounds (USs) in the Extraction of Anthocyanins}

Ultrasounds (USs) are mechanic waves with a frequency above $20 \mathrm{kHz}$, which is not perceptible to the human ear (typically in the range $20 \mathrm{~Hz}-20 \mathrm{kHz}$ ) [77]. It is a key technology for obtaining bioactive compounds (e.g., anthocyanins), like the others described above, as it can be considered a sustainable 'green' extraction method [78] as it does not use organic solvents and is gentle to heat-sensitive molecules [79]. The compression and rarefaction of the products produced by the US waves produce the successive reduction in size and expansion of the bubbles formed by cavitation (Figure 8). When these bubbles collapse, large amounts of energy are released, reaching localized temperatures of $5000^{\circ} \mathrm{K}$ and pressures of $200 \mathrm{MPa}$ [80]. These phenomena are responsible for the depolymerization of biostructures [80] and facilitate the extraction of molecules from plant tissues. Depolymerization can occur by bubble collapse, cavitation or degradation of the polymer by impact with radicals formed during sonication [81]. Depolymerization of cell wall polysaccharides accelerates the release of anthocyanins from the skin cells in grapes (Figure 9). The extraction of anthocyanins in water within a few minutes and the increase in temperature due to the cavitation effect can be observed. High power ultrasounds with the best extraction potential are considered to be in the range of $20-25 \mathrm{kHz}$ [78].

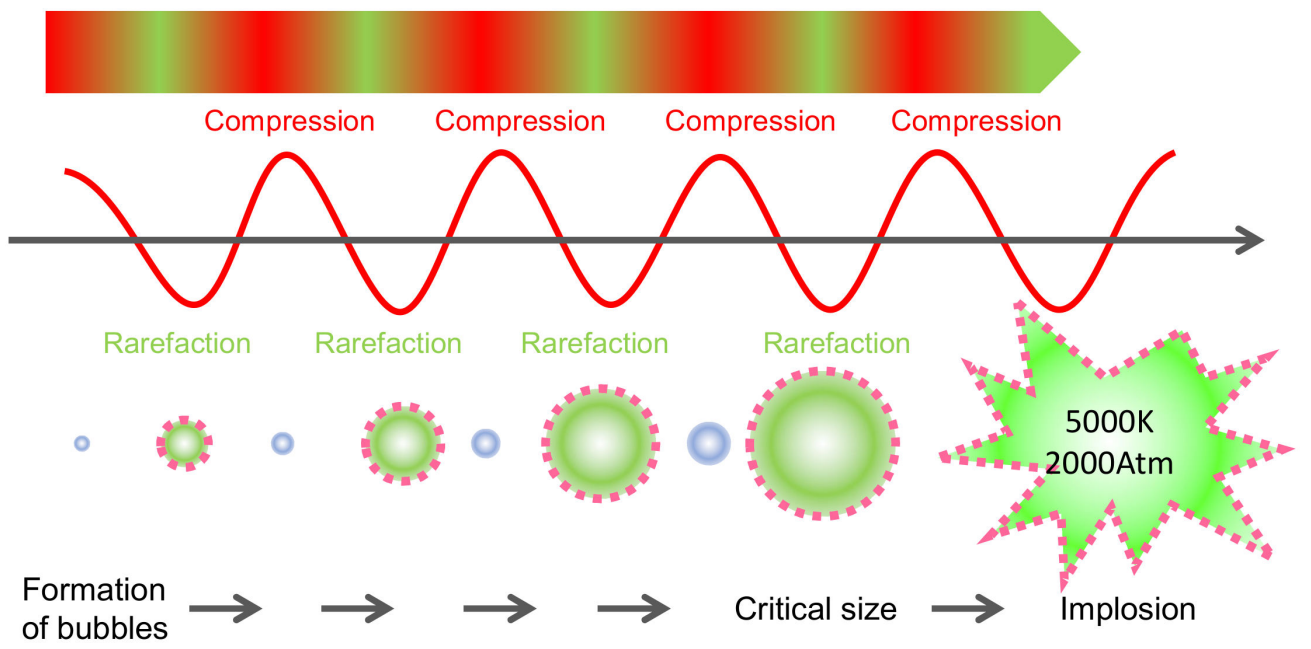

Figure 8. Implosion of bubbles and cavitation produced by alternative compression-rarefaction effects generated by US waves [22].

Figure 9 shows the application of USs on grape berries by means of a sonotrode and reveals, after a few minutes, how the anthocyanins are extracted to the surrounding media (water) due to the depolymerization of the cell walls of the grape skins. Additionally, the heating effect produced by cavitation can be observed, which in this case is about $5{ }^{\circ} \mathrm{C}$ in the center of the flask according to infrared thermography.

There are several systems for applying USs to plant tissues with the aim of favoring the extraction of compounds: Ultrasound baths, sonotrodes, sonoplates. However, on an industrial scale, the most effective system is the use of continuous tubular exchangers on the external surface of which sonoplates are distributed to apply US waves during the flow of the mash or liquid through the exchanger. For a better distribution of the sonoplates on the exchange surface, the section is usually hexagonal instead of circular (Figure 10). 

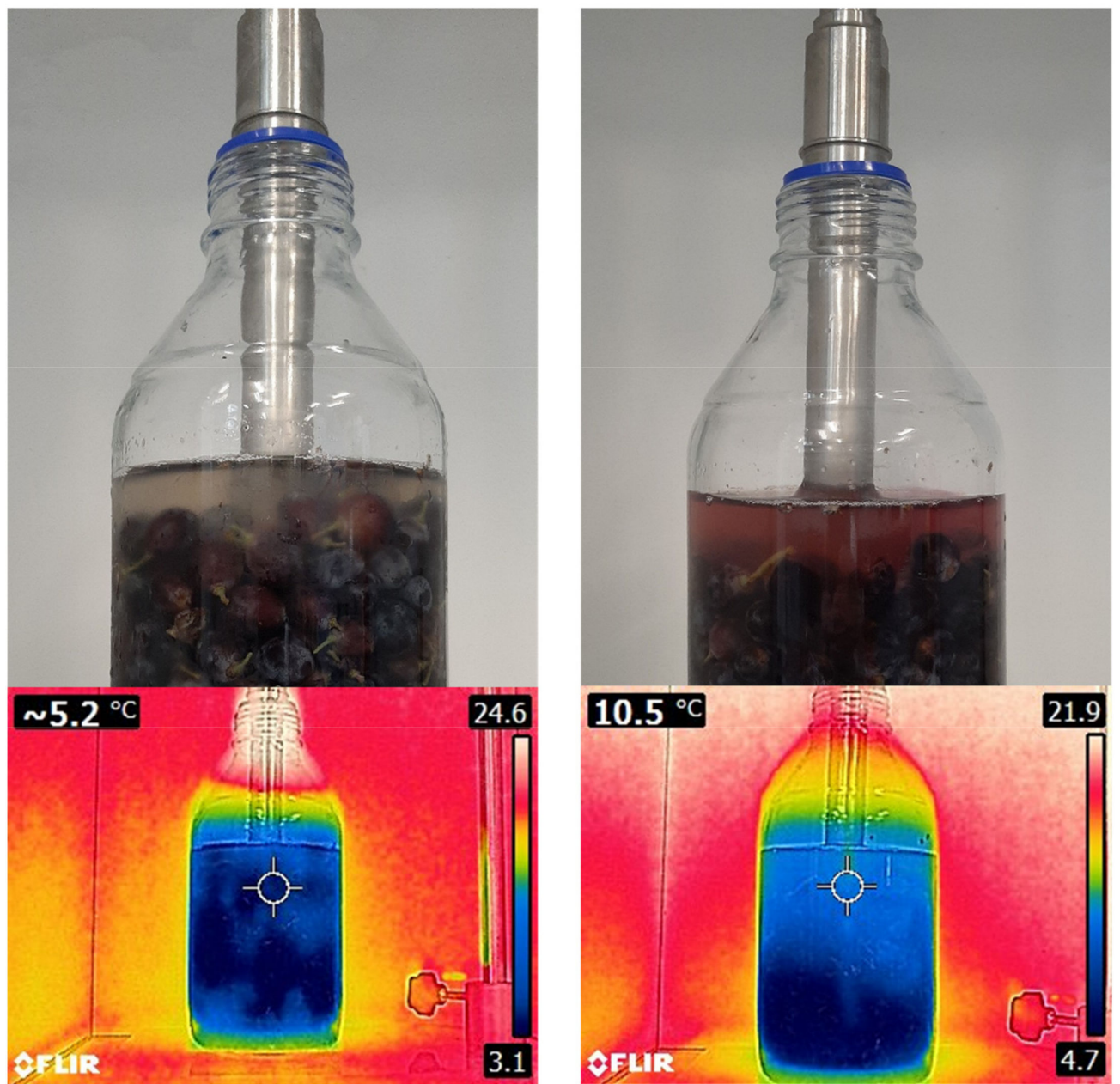

Figure 9. Use of USs in the extraction of grape anthocyanins and effect on temperature measured with an infrared camera. Left: before ultrasonication, right: after US treatment.

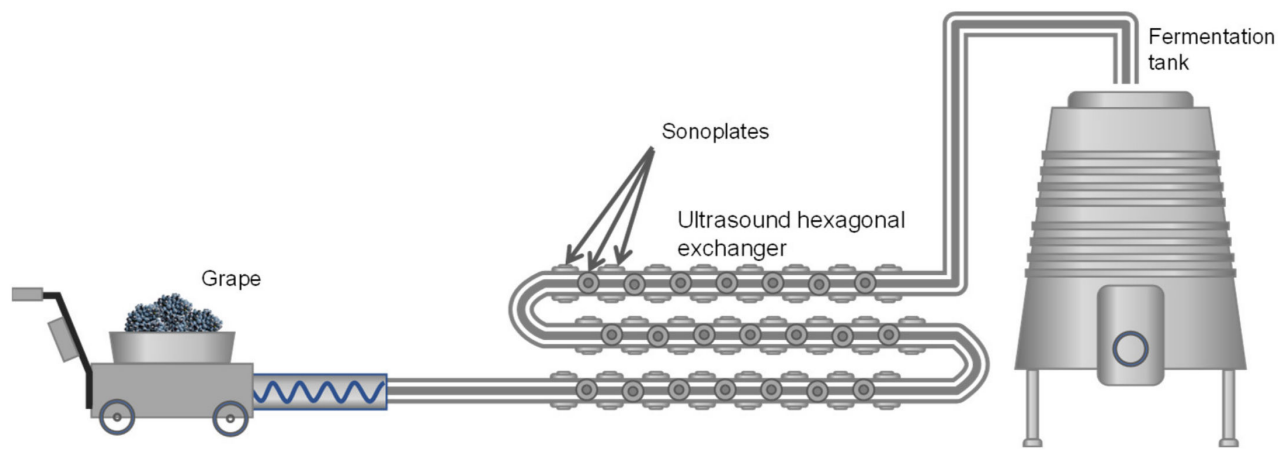

Figure 10. Cavitation cells arranged in a hexagonal tubular exchanger with the sonoplates for applying US waves [22].

This technology has been used to process Tempranillo grapes, achieving the same anthocyanin content in a final wine after only continuous US treatment and $72 \mathrm{~h}$ of skin maceration as in the control wine [82]. In discontinuous treatment at the laboratory scale, the USs have been shown to increase the extraction of anthocyanins and phenols by more than 50\% compared to controls [56]. US can also be applied continuously after the application of pectolytic enzymes at industrial level, increasing color intensity by $18 \%$ and total polyphenols by $21 \%$ in wines [57]. The use of US-assisted extraction can be improved by optimizing other physicochemical parameters (temperature, ethanol and time), thus reaching a maximum of $6.26 \mathrm{mg} / \mathrm{mL}$ under the best conditions of $45.14{ }^{\circ} \mathrm{C}, 52.3 \%$ ethanol 
and $24.5 \mathrm{~min}$ [83]. USs can be used to improve extraction and/or reduce extraction time in grapes [56,57,82], and by-products such as pomace [33] and lees [58]. USs have been applied to Vitis vinifera L. varieties Cabernet Franc [84], Tempranillo [82], Tannat [56], and Monastrell [57]. The influence of the US frequency has also been analyzed, considering the values of $12.5,25$, and $37.5 \mathrm{kHz}$, as well as from 12.5 to $25 \mathrm{kHz}$, the extraction of anthocyanins increased by $18 \%$ in grape pomace, however, the higher the frequency, the lower the extraction [59].

\section{Effect of E-Beam Irradiation in the Extraction of Anthocyanins}

Electron beam (e-beam) irradiation or $\beta$-irradiation involves the use of accelerated electrons at high energy, typically $10 \mathrm{MeV}[21,37,85]$, to process foods and eliminate microorganisms, allowing pasteurization (1-5 kGy) or sterilization (>10 kGy) depending on the dose $[21,37,85]$. The irradiation dose is measured in Grays (Gy) or kGrays (kGy). One $\mathrm{Gy}$ is defined as the absorption of 1 Joule of energy per $\mathrm{kg}$ of irradiated mass. Irradiation is widely used to preserve food in more than 55 countries and is considered a safe technology approved by WHO, FAO and IAEA [86]. This technique is cheap on a large scale, environmentally friendly and time efficient [87]. e-Beam irradiation is a complex technology that requires expensive irradiation accelerators and large-scale facilities. e-Beam irradiation can be applied on an industrial scale in a continuous process [21]. The radiation dose can be monitored and verified by placing radiochromic dosimeters on the treated food (Figure 11). This can be used to verify the real dose received by the food at every width. e-Beam irradiation can be considered a gentle non-thermal technology with temperature increments of less than $5^{\circ} \mathrm{C}$ at doses up to $10 \mathrm{kGy}$ [21]. In addition, e-beam irradiation has been proposed as an alternative to sulphites in wine preservation [88] and has demonstrated its ability to delay browning in plant foods [89]. However, some negative effects have been observed such as loss of aroma [37] and reduction in vitamin C content [85], due to free radical-mediated oxidation [90].

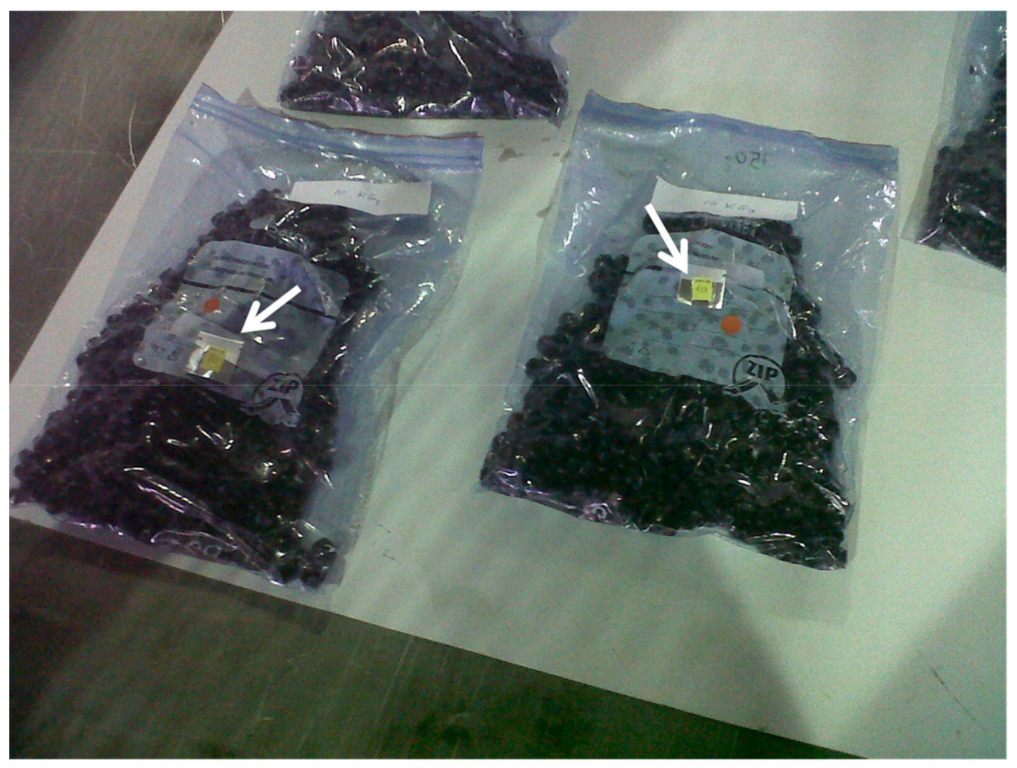

Figure 11. Red grapes in plastic bags after e-beam irradiation. The white arrows indicate the location of radiochromic dosimeters.

Even when the external appearance of the grapes after irradiation remains unchanged (Figure 12A), the release of some juice in the bags can be observed, especially at high doses $(10 \mathrm{kGy})$. This leakage of juice from the grapes shows the weakening of the plant tissues due to irradiation. The main effect of e-beam irradiation on plant tissues is the fragmentation of fibrillar polymers such as pectins and other polysaccharides, promoting the release and extraction of cell components, including anthocyanins. It has been reported 
that the molecular weight of pectins can be reduced by $90 \%$ using doses of 3-10 kGy [91]. The effect on grapes is the increased extraction of phenols and anthocyanins [37], which can be observed in the more intense color of the running juice, especially when grapes are processed at $10 \mathrm{kGy}$ (Figure 12B). Up to $1 \mathrm{kGy}$, the anthocyanin extraction is low and not too high compared to the controls, however at $10 \mathrm{kGy}$, the anthoyanins extracted in the running juice were $125 \mathrm{mg} / \mathrm{L}$ compared with $72 \mathrm{mg} / \mathrm{L}$ on average in the controls $(+71 \%)$ [37]. Better antioxidant and sensory properties and higher phenol content have also been observed in grapes processed up to $2 \mathrm{kGy}$ [92]. With blueberries, the use of e-beam irradiation at doses below $3 \mathrm{kGy}$ has demonstrated to be a gentle processing that does not affect monomeric anthocyanin and antioxidant activity [93]. Protection of anthocyanins, color, phenols and antioxidant activity has also been observed in strawberries processed at 1 kGy [94].

A

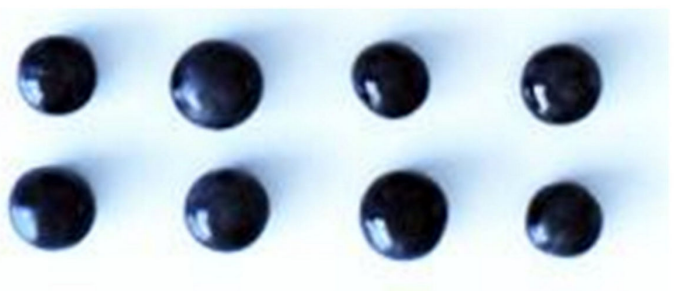
Control
0.5
1
$10 \mathrm{kGy}$

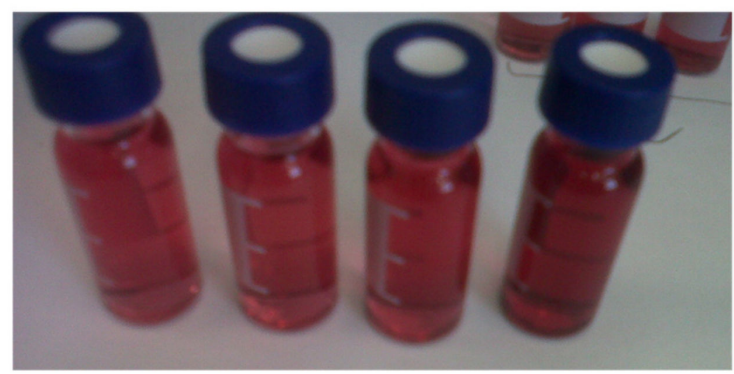

Figure 12. Effect of e-beam irradiation on the external appearance of grapes (A). Running juice from grapes processed by e-beam irradiation at various doses (B).

\section{Pulsed Light}

Pulsed light (PL) treatment involves the application of high-intensity, low-duration pulses of radiation in the $200 \mathrm{~nm}$ (UV) to $2500 \mathrm{~nm}$ (IR) range [95,96]. The intensity can be higher than $10^{6}$ fold that of sunlight at sea level in the summer midday and the duration ranges from micro to milliseconds. Detailed parameters for pulsed light processing conditions have recently been revised [97]. The temperature rise after standard PL treatments is usually less than $5{ }^{\circ} \mathrm{C}$, so it can be considered a mild non-thermal technology that can be used in delicate foods [96].

The ability to extract anthocyanins and phenols from plant tissues is lower than some of the previous techniques and the literature reports inconclusive results. Non-significant differences have been found in the anthocyanin content of wines made from PL-processed grapes compared to controls [98]. Temperature increases in grape skins of $2-3{ }^{\circ} \mathrm{C}$ after pulsed light treatments have also been reported without severe damage to the skin surface observed by AFM scanning [99]. Furthermore, PL processing of strawberries at $4-8 \mathrm{~J} / \mathrm{cm}^{2}$ does not affect the quality and antioxidant capacity [100].

\section{Conclusions}

The use of emerging non-thermal technologies is a successful tool for the extraction of anthocyanins from grapes, increasing the yield, accelerating the process and preserving the antioxidant capacity. Many of these techniques can be applied in continuous flow (UHPH, PEF, US, Irradiation and PL), which is suitable for industrial processing. Most of 
these techniques can work at room temperature or even using refrigerated crushed grapes, although temperature is always a synergistic parameter. These technologies can be used for the extraction of anthocyanins from grapes, and also from by-products such as pomace, generating high-value pigments from them. Additionally, emerging technologies can be used to improve the winemaking process by increasing the extraction of anthocyanins and phenolic compounds in maceration and controlling oxidations.

Author Contributions: Conceptualization, A.M.; methodology, A.M. and C.G.; writing-original draft preparation, A.M., C.E., I.L., C.L., F.P.; writing-review and editing, A.M., C.E., I.L., C.L., F.P. and C.G.; funding acquisition, A.M. All authors have read and agreed to the published version of the manuscript.

Funding: This study was funded by Ministerio de Ciencia, Innovación y Universidades project: RTI2018-096626-B-I00.

Conflicts of Interest: The authors declare no conflict of interest.

\section{References}

1. Mazza, G.; Francis, D.F.J. Anthocyanins in grapes and grape products. Crit. Rev. Food Sci. Nutr. 2009, 35, 341-371. [CrossRef] [PubMed]

2. Bridle, P.; Timberlake, C.F. Anthocyanins as natural food colours-Selected aspects. Food Chem. 1997, 58, 103-109. [CrossRef]

3. Harborne, J.B.; Williams, C.A. Anthocyanins and other flavonoids. Nat. Prod. Rep. 2001, 18, 310-333. [CrossRef] [PubMed]

4. He, F.; Liang, N.-N.; Mu, L.; Pan, Q.-H.; Wang, J.; Reeves, M.J.; Duan, C.-Q. Anthocyanins and Their Variation in Red Wines I. Monomeric Anthocyanins and Their Color Expression. Molecules 2012, 17, 1571-1601. [CrossRef] [PubMed]

5. Khoo, H.; Azlan, A.; Tang, S.; Lim, S. Anthocyanidins and anthocyanins: Colored pigments as food, pharmaceutical ingredients, and the potential health benefits. Food Nutr. Res. 2017, 61, 1361779. [CrossRef]

6. Escribano-Bailón, M.T.; Rivas-Gonzalo, J.C.; García-Estévez, I. Wine Color Evolution and Stability. In Red Wine Technology; Academic Press: New York, NY, USA, 2019; pp. 195-205.

7. Morata, A.; López, C.; Tesfaye, W.; González, C.; Escott, C. Anthocyanins as natural pigments in beverages. In Value-Added Ingredients and Enrichments of Beverages; Academic Press: New York, NY, USA, 2019; pp. 383-428.

8. Santos-Buelga, C.; González-Paramás, A.M. Anthocyanins. In Encyclopedia of Food Chemistry; Academic Press: Cambridge, MA, USA, 2019; pp. 10-21.

9. Mazza, G.; Miniati, E. Anthocyanins in Fruits, Vegetables, and Grains, 1st ed.; CRC Press: Boca Raton, FL, USA, 2018; ISBN 9781351069700.

10. Jackman, R.L.; Yada, R.Y.; Tung, M.A.; Speers, R.A. Anthocyanins as Food Colorants-A Review. J. Food Biochem. 1987, 11, 201-247. [CrossRef]

11. Mateus, N.; de Freitas, V. Anthocyanins as Food Colorants. In Anthocyanins; Winefield, C., Davies, K., Gould, K., Eds.; Springer: New York, NY, USA, 2008; pp. 284-304.

12. Roy, S.; Rhim, J.-W. Anthocyanin food colorant and its application in $\mathrm{pH}$-responsive color change indicator films. Crit. Rev. Food Sci. Nutr. 2020, 61, 2297-2325. [CrossRef]

13. Tena, N.; Martín, J.; Asuero, A.G. State of the Art of Anthocyanins: Antioxidant Activity, Sources, Bioavailability, and Therapeutic Effect in Human Health. Antioxidants 2020, 9, 451. [CrossRef]

14. Speer, H.; D'Cunha, N.M.; Alexopoulos, N.I.; McKune, A.J.; Naumovski, N. Anthocyanins and Human Health-A Focus on Oxidative Stress, Inflammation and Disease. Antioxidants 2020, 9, 366. [CrossRef] [PubMed]

15. Hair, R.; Sakaki, J.R.; Chun, O.K. Anthocyanins, Microbiome and Health Benefits in Aging. Molecules 2021, 26, 537. [CrossRef]

16. Morata, A.; Escott, C.; Loira, I.; Manuel Del Fresno, J.; González, C.; Suárez-Lepe, J.A. Influence of Saccharomyces and nonSaccharomyces yeasts in the formation of pyranoanthocyanins and polymeric pigments during red wine making. Molecules 2019, 24, 4490. [CrossRef]

17. Monagas, M.; Núñez, V.; Bartolomé, B.; Gómez-Cordovés, C. Anthocyanin-derived pigments in Graciano, Tempranillo, and Cabernet Sauvignon wines produced in Spain. Am. J. Enol. Vitic. 2003, 54, 163-169.

18. Morata, A.; González, C.; Tesfaye, W.; Loira, I.; Suárez-Lepe, J.A. Maceration and fermentation: New technologies to increase extraction. In Red Wine Technology; Elsevier: Amsterdam, The Netherlands, 2019; pp. 35-49.

19. Busse-Valverde, N.; Gómez-Plaza, E.; López-Roca, J.M.; Gil-Muñoz, R.; Bautista-Ortín, A.B. The Extraction of Anthocyanins and Proanthocyanidins from Grapes to Wine during Fermentative Maceration Is Affected by the Enological Technique. J. Agric. Food Chem. 2011, 59, 5450-5455. [CrossRef] [PubMed]

20. Río Segade, S.; Pace, C.; Torchio, F.; Giacosa, S.; Gerbi, V.; Rolle, L. Impact of maceration enzymes on skin softening and relationship with anthocyanin extraction in wine grapes with different anthocyanin profiles. Food Res. Int. 2015, 71, 50-57. [CrossRef] 
21. Morata, A.; Loira, I.; Vejarano, R.; González, C.; Callejo, M.J.; Suárez-Lepe, J.A. Emerging preservation technologies in grapes for winemaking. Trends Food Sci. Technol. 2017, 67, 36-43. [CrossRef]

22. Morata, A.; Loira, I.; Guamis, B.; Raso, J.; del Fresno, J.M.; Escott, C.; Bañuelos, M.A.; Álvarez, I.; Tesfaye, W.; González, C.; et al. Emerging technologies to increase extraction, control microorganisms, and reduce $\mathrm{SO}_{2}$. In Chemistry and Biochemistry of Winemaking, Wine Stabilization and Aging; IntechOpen: Rijeka, Croatia, 2020; pp. 1-20. ISBN 978-1-83962-576-3.

23. Corrales, M.; García, A.F.; Butz, P.; Tauscher, B. Extraction of anthocyanins from grape skins assisted by high hydrostatic pressure. J. Food Eng. 2009, 90, 415-421. [CrossRef]

24. Morata, A.; Loira, I.; Vejarano, R.; Bañuelos, M.A.; Sanz, P.D.; Otero, L.; Suárez-Lepe, J.A. Grape processing by High Hydrostatic Pressure: Effect on microbial populations, phenol extraction and wine quality. Food Bioprocess Technol. 2014, 8, 277-286. [CrossRef]

25. Morata, A.; Guamis, B. Use of UHPH to obtain juices with better nutritional quality and healthier wines with low levels of $\mathrm{SO}_{2}$. Front. Nutr. 2020, 7, 598286. [CrossRef] [PubMed]

26. Corrales, M.; Toepfl, S.; Butz, P.; Knorr, D.; Tauscher, B. Extraction of anthocyanins from grape by-products assisted by ultrasonics, high hydrostatic pressure or pulsed electric fields: A comparison. Innov. Food Sci. Emerg. Technol. 2008, 9, 85-91. [CrossRef]

27. López, N.; Puértolas, E.; Condón, S.; Álvarez, I.; Raso, J. Effects of pulsed electric fields on the extraction of phenolic compounds during the fermentation of must of Tempranillo grapes. Innov. Food Sci. Emerg. Technol. 2008, 9, 477-482. [CrossRef]

28. Puértolas, E.; López, N.; Condón, S.; Álvarez, I.; Raso, J. Potential applications of PEF to improve red wine quality. Trends Food Sci. Technol. 2010, 21, 247-255. [CrossRef]

29. Puértolas, E.; Saldaña, G.; Álvarez, I.; Raso, J. Experimental design approach for the evaluation of anthocyanin content of rosé wines obtained by pulsed electric fields. Influence of temperature and time of maceration. Food Chem. 2011, 126, 1482-1487. [CrossRef]

30. Ghafoor, K.; Choi, Y.H.; Jeon, J.Y.; Jo, I.H. Optimization of Ultrasound-Assisted Extraction of Phenolic Compounds, Antioxidants, and Anthocyanins from Grape (Vitis vinifera) Seeds. J. Agric. Food Chem. 2009, 57, 4988-4994. [CrossRef]

31. Tiwari, B.K.; Patras, A.; Brunton, N.; Cullen, P.J.; O'Donnell, C.P. Effect of ultrasound processing on anthocyanins and color of red grape juice. Ultrason. Sonochem. 2010, 17, 598-604. [CrossRef]

32. Liazid, A.; Barbero, G.F.; Azaroual, L.; Palma, M.; Barroso, C.G. Stability of Anthocyanins from Red Grape Skins under Pressurized Liquid Extraction and Ultrasound-Assisted Extraction Conditions. Molecules 2014, 19, 21034-21043. [CrossRef] [PubMed]

33. Bonfigli, M.; Godoy, E.; Reinheimer, M.A.; Scenna, N.J. Comparison between conventional and ultrasound-assisted techniques for extraction of anthocyanins from grape pomace. Experimental results and mathematical modeling. J. Food Eng. 2017, 207, 56-72. [CrossRef]

34. Tan, J.; Li, Q.; Xue, H.; Tang, J. Ultrasound-assisted enzymatic extraction of anthocyanins from grape skins: Optimization, identification, and antitumor activity. J. Food Sci. 2020, 85, 3731-3744. [CrossRef] [PubMed]

35. Ayed, N.; Yu, H.L.; Lacroix, M. Improvement of anthocyanin yield and shelf-life extension of grape pomace by gamma irradiation. Food Res. Int. 1999, 32, 539-543. [CrossRef]

36. Ayed, N.; Yu, H.L.; Lacroix, M. Using gamma irradiation for the recovery of anthocyanins from grape pomace. Radiat. Phys. Chem. 2000, 57, 277-279. [CrossRef]

37. Morata, A.; Bañuelos, M.A.; Tesfaye, W.; Loira, I.; Palomero, F.; Benito, S.; Callejo, M.J.; Villa, A.; González, M.C.; Suárez-Lepe, J.A. Electron Beam Irradiation of wine grapes: Effect on microbial populations, phenol extraction and wine quality. Food Bioprocess Technol. 2015, 8, 1845-1853. [CrossRef]

38. Bermúdez-Aguirre, D.; Barbosa-Cánovas, G.V. An Update on High Hydrostatic Pressure, from the Laboratory to Industrial Applications. Food Eng. Rev. 2010, 3, 44-61. [CrossRef]

39. Yamamoto, K. Food processing by high hydrostatic pressure. Biosci. Biotechnol. Biochem. 2017, 81, 672-679. [CrossRef] [PubMed]

40. Huang, H.W.; Hsu, C.P.; Wang, C.Y. Healthy expectations of high hydrostatic pressure treatment in food processing industry. J. Food Drug Anal. 2020, 28, 1-13. [CrossRef] [PubMed]

41. Zamora, A.; Guamis, B. Opportunities for Ultra-High-Pressure Homogenisation (UHPH) for the Food Industry. Food Eng. Rev. 2014, 7, 130-142. [CrossRef]

42. Buzrul, S. High hydrostatic pressure treatment of beer and wine: A review. Innov. Food Sci. Emerg. Technol. 2012, 13, 1-12. [CrossRef]

43. Martín, J.; Asuero, A.G. High hydrostatic pressure for recovery of anthocyanins: Effects, performance, and applications. Sep. Purif. Rev. 2021, 50, 159-176. [CrossRef]

44. Tiwari, B.K.; O’Donnell, C.P.; Cullen, P.J. Effect of non thermal processing technologies on the anthocyanin content of fruit juices. Trends Food Sci. Technol. 2009, 20, 137-145. [CrossRef]

45. Bañuelos, M.A.; Loira, I.; Escott, C.; Del Fresno, J.M.; Morata, A.; Sanz, P.D.; Otero, L.; Suárez-Lepe, J.A. Grape processing by High Hydrostatic Pressure: Effect on use of non-Saccharomyces in must fermentation. Food Bioprocess Technol. 2016, 9, 1769-1778. [CrossRef]

46. Christofi, S.; Malliaris, D.; Katsaros, G.; Panagou, E.; Kallithraka, S. Limit $\mathrm{SO}_{2}$ content of wines by applying High Hydrostatic Pressure. Innov. Food Sci. Emerg. Technol. 2020, 62, 102342. [CrossRef]

47. Vaquero, C.; Escott, C.; Loira, I.; Guamis, B.; Del Fresno, J.M.; Quevedo, J.M.; Gervilla, R.; De Lamo, S.; Ferrer-Gallego, R.; González, C.; et al. Cabernet sauvignon red wine processing by $\mathrm{UHPH}$ without $\mathrm{SO}_{2}$. Colloidal structure, microbial and oxidation control, colour protection and sensory quality of wine. 2021; submitted. 
48. Tedjo, W.; Eshtiaghi, M.N.; Knorr, D. Einsatz nicht-thermischer Verfahren zur Zellpermeabilisierung von Weintrauben und Gewinnung von Inhaltsstoffen. Fluss. Obs. 2002, 69, 578-585.

49. López, N.; Puértolas, E.; Condón, S.; Álvarez, I.; Raso, J. Application of pulsed electric fields for improving the maceration process during vinification of red wine: Influence of grape variety. Eur. Food Res. Technol. 2008, 227, 1099-1107. [CrossRef]

50. Leong, S.Y.; Burritt, D.J.; Oey, I. Evaluation of the anthocyanin release and health-promoting properties of Pinot Noir grape juices after pulsed electric fields. Food Chem. 2016, 196, 833-841. [CrossRef]

51. Puértolas, E.; López, N.; Saldaña, G.; Álvarez, I.; Raso, J. Evaluation of phenolic extraction during fermentation of red grapes treated by a continuous pulsed electric fields process at pilot-plant scale. J. Food Eng. 2010, 98, 120-125. [CrossRef]

52. Luengo, E.; Franco, E.; Ballesteros, F.; Álvarez, I.; Raso, J. Winery Trial on Application of Pulsed Electric Fields for Improving Vinification of Garnacha Grapes. Food Bioprocess Technol. 2013, 7, 1457-1464. [CrossRef]

53. Leong, S.Y.; Treadwell, M.; Liu, T.; Hochberg, M.; Sack, M.; Mueller, G.; Sigler, J.; Silcock, P.; Oey, I. Influence of Pulsed Electric Fields processing at high-intensity electric field strength on the relationship between anthocyanins composition and colour intensity of Merlot (Vitis vinifera L.) musts during cold maceration. Innov. Food Sci. Emerg. Technol. 2020, 59, 102243. [CrossRef]

54. Comuzzo, P.; Voce, S.; Grazioli, C.; Tubaro, F.; Marconi, M.; Zanella, G.; Querzè, M. Pulsed Electric Field processing of red grapes (cv. Rondinella): Modifications of phenolic fraction and effects on wine evolution. Foods 2020, 9, 414. [CrossRef] [PubMed]

55. Vaquero, C.; Loira, I.; Raso, J.; Álvarez, I.; Delso, C.; Morata, A. Pulsed Electric Fields to Improve the Use of Non-Saccharomyces Starters in Red Wines. Foods 2021, 10, 1472. [CrossRef]

56. González, M.; Barrios, S.; Budelli, E.; Pérez, N.; Lema, P.; Heinzen, H. Ultrasound assisted extraction of bioactive compounds in fresh and freeze-dried Vitis vinifera cv Tannat grape pomace. Food Bioprod. Process. 2020, 124, 378-386. [CrossRef]

57. Osete-Alcaraz, A.; Bautista-Ortín, A.B.; Ortega-Regules, A.E.; Gómez-Plaza, E. Combined Use of Pectolytic Enzymes and Ultrasounds for Improving the Extraction of Phenolic Compounds During Vinification. Food Bioprocess Technol. 2019, 12, 13301339. [CrossRef]

58. Romero-Díez, R.; Matos, M.; Rodrigues, L.; Bronze, M.R.; Rodríguez-Rojo, S.; Cocero, M.J.; Matias, A.A. Microwave and ultrasound pre-treatments to enhance anthocyanins extraction from different wine lees. Food Chem. 2019, 272, 258-266. [CrossRef] [PubMed]

59. Dranca, F.; Oroian, M. Kinetic Improvement of Bioactive Compounds Extraction from Red Grape (Vitis vinifera Moldova) Pomace by Ultrasonic Treatment. Foods 2019, 8, 353. [CrossRef] [PubMed]

60. Patrignani, F.; Lanciotti, R. Applications of High and Ultra High Pressure Homogenization for Food Safety. Front. Microbiol. 2016, 7, 1132. [CrossRef] [PubMed]

61. Comuzzo, P.; Calligaris, S. Potential Applications of High Pressure Homogenization in Winemaking: A Review. Beverages 2019, 5, 56. [CrossRef]

62. Loira, I.; Morata, A.; Bañuelos, M.A.; Puig-Pujol, A.; Guamis, B.; González, C.; Suárez-Lepe, J.A. Use of Ultra-High Pressure Homogenization processing in winemaking: Control of microbial populations in grape musts and effects in sensory quality. Innov. Food Sci. Emerg. Technol. 2018, 50, 50-56. [CrossRef]

63. Marszałek, K.; Woźniak, Ł.; Kruszewski, B.; Skapska, S. The Effect of High Pressure Techniques on the Stability of Anthocyanins in Fruit and Vegetables. Int. J. Mol. Sci. 2017, 18, 277. [CrossRef]

64. Bañuelos, M.A.; Loira, I.; Buenaventura, G.; Escott, C.; del Fresno, J.M.; Codina-Torrella, I.; Quevedo, J.M.; Gervilla, R.; Rodríguez Chavarría, J.M.; de Lamo, S.; et al. White wine processing by $\mathrm{UHPH}$ without $\mathrm{SO}_{2}$. Elimination of microbial populations and effect in oxidative enzymes, colloidal stability and sensory quality. Food Chem. 2020, 332, 127417. [CrossRef]

65. Bevilacqua, A.; Petruzzi, L.; Perricone, M.; Speranza, B.; Campaniello, D.; Sinigaglia, M.; Corbo, M.R. Nonthermal Technologies for Fruit and Vegetable Juices and Beverages: Overview and Advances. Compr. Rev. Food Sci. Food Saf. 2018, 17, 2-62. [CrossRef]

66. Guamis López, B.; Trujillo Mesa, A.J.; Ferragut Péréz, V.; Quevedo Terré, J.M.; Lopez Pedemonte, T.; Buffa Dunat, M.N. Continuous System and Procedure of Sterilization and Physical Stabilization of Pumpable Fluids by Means of Ultra-High Pressure Homogenization. Patent Number ES2543365T3, 18 August 2015. Available online: https:/ / patents.google.com/patent/ES25433 65T3/en (accessed on 2 November 2021).

67. Barbosa-Canovas, G.V.; Pothakamury, U.R.; Gongora-Nieto, M.M.; Swanson, B.G. Preservation of Foods with Pulsed Electric Fields; Taylor, S.L., Ed.; Elsevier: San Diego, CA, USA, 1999.

68. Soliva-Fortuny, R.; Balasa, A.; Knorr, D.; Martín-Belloso, O. Effects of pulsed electric fields on bioactive compounds in foods: A review. Trends Food Sci. Technol. 2009, 20, 544-556. [CrossRef]

69. Toepfl, S.; Siemer, C.; Saldaña-Navarro, G.; Heinz, V. Overview of Pulsed Electric Fields Processing for Food. In Emerging Technologies for Food Processing; Sun, D.-W., Ed.; Academic Press: London, UK, 2014; pp. 93-114.

70. Barba, F.J.; Parniakov, O.; Pereira, S.A.; Wiktor, A.; Grimi, N.; Boussetta, N.; Saraiva, J.A.; Raso, J.; Martin-Belloso, O.; WitrowaRajchert, D.; et al. Current applications and new opportunities for the use of pulsed electric fields in food science and industry. Food Res. Int. 2015, 77, 773-798. [CrossRef]

71. Gabrić, D.; Barba, F.; Roohinejad, S.; Gharibzahedi, S.M.T.; Radojčin, M.; Putnik, P.; Kovačević, D.B. Pulsed electric fields as an alternative to thermal processing for preservation of nutritive and physicochemical properties of beverages: A review. J. Food Process Eng. 2018, 41, e12638. [CrossRef]

72. Barba, F.J.; Grimi, N.; Vorobiev, E. New Approaches for the Use of Non-conventional Cell Disruption Technologies to Extract Potential Food Additives and Nutraceuticals from Microalgae. Food Eng. Rev. 2014, 7, 45-62. [CrossRef] 
73. Angersbach, A.; Heinz, V.; Knorr, D. Effects of pulsed electric fields on cell membranes in real food systems. Innov. Food Sci. Emerg. Technol. 2000, 1, 135-149. [CrossRef]

74. Heinz, V.; Alvarez, I.; Angersbach, A.; Knorr, D. Preservation of liquid foods by high intensity pulsed electric fields-basic concepts for process design. Trends Food Sci. Technol. 2001, 12, 103-111. [CrossRef]

75. Arcena, M.R.; Leong, S.Y.; Then, S.; Hochberg, M.; Sack, M.; Mueller, G.; Sigler, J.; Kebede, B.; Silcock, P.; Oey, I. The effect of pulsed electric fields pre-treatment on the volatile and phenolic profiles of Merlot grape musts at different winemaking stages and the sensory characteristics of the finished wines. Innov. Food Sci. Emerg. Technol. 2021, 70, 102698. [CrossRef]

76. Martin, M.E.; Grao-Cruces, E.; Millan-Linares, M.C.; Montserrat-de la Paz, S. Grape (Vitis vinifera L.) Seed Oil: A Functional Food from the Winemaking Industry. Foods 2020, 9, 1360. [CrossRef] [PubMed]

77. Kumar, K.; Srivastav, S.; Sharanagat, V.S. Ultrasound assisted extraction (UAE) of bioactive compounds from fruit and vegetable processing by-products: A review. Ultrason. Sonochem. 2021, 70, 105325. [CrossRef]

78. Chemat, F.; Rombaut, N.; Sicaire, A.G.; Meullemiestre, A.; Fabiano-Tixier, A.S.; Abert-Vian, M. Ultrasound assisted extraction of food and natural products. Mechanisms, techniques, combinations, protocols and applications. A review. Ultrason. Sonochem. 2017, 34, 540-560. [CrossRef]

79. Tiwari, B.K. Ultrasound: A clean, green extraction technology. TrAC Trends Anal. Chem. 2015, 71, 100-109. [CrossRef]

80. Chemat, F.; Zill-E-Huma; Khan, M.K. Applications of ultrasound in food technology: Processing, preservation and extraction. Ultrason. Sonochem. 2011, 18, 813-835. [CrossRef] [PubMed]

81. Grönroos, A.; Pirkonen, P.; Ruppert, O. Ultrasonic depolymerization of aqueous carboxymethylcellulose. Ultrason. Sonochem. 2004, 11, 9-12. [CrossRef]

82. Gómez-Plaza, E.; Jurado, R.; Iniesta, J.A.; Bautista-Ortín, A.B. High power ultrasounds: A powerful, non-thermal and green technique for improving the phenolic extraction from grapes to must during red wine vinification. BIO Web Conf. 2019, 12, 1-5.

83. Ghafoor, K.; Hui, T.; Choi, Y.H. Optimization of ultrasonic-assited extraction of total anthocyanins from grape peel using response surface methodology. J. Food Biochem. 2011, 35, 735-746. [CrossRef]

84. El Darra, N.; Grimi, N.; Maroun, R.G.; Louka, N.; Vorobiev, E. Pulsed electric field, ultrasound, and thermal pretreatments for better phenolic extraction during red fermentation. Eur. Food Res. Technol. 2012, 236, 47-56. [CrossRef]

85. Elias, M.I.; Madureira, J.; Santos, P.M.P.; Carolino, M.M.; Margaça, F.M.A.; Cabo Verde, S. Preservation treatment of fresh raspberries by e-beam irradiation. Innov. Food Sci. Emerg. Technol. 2020, 66, 102487. [CrossRef]

86. Farkas, J.; Mohácsi-Farkas, C. History and future of food irradiation. Trends Food Sci. Technol. 2011, 22, 121-126. [CrossRef]

87. Lung, H.M.; Cheng, Y.C.; Chang, Y.H.; Huang, H.W.; Yang, B.B.; Wang, C.Y. Microbial decontamination of food by electron beam irradiation. Trends Food Sci. Technol. 2015, 44, 66-78. [CrossRef]

88. Błaszak, M.; Nowak, A.; Lachowicz, S.; Migdał, W.; Ochmian, I. E-Beam Irradiation and Ozonation as an Alternative to the Sulphuric Method of Wine Preservation. Molecules 2019, 24, 3406. [CrossRef]

89. Fernandes, Â.; Antonio, A.L.; Oliveira, M.B.P.P.; Martins, A.; Ferreira, I.C.F.R. Effect of gamma and electron beam irradiation on the physico-chemical and nutritional properties of mushrooms: A review. Food Chem. 2012, 135, 641-650. [CrossRef]

90. Wong, P.Y.Y.; Kitts, D.D. Factors influencing ultraviolet and electron beam irradiation-induced free radical damage of ascorbic acid. Food Chem. 2001, 74, 75-84. [CrossRef]

91. Gamonpilas, C.; Buathongjan, C.; Sangwan, W.; Rattanaprasert, M.; Weizman, K.C.; Klomtun, M.; Phonsatta, N.; Methacanon, P. Production of low molecular weight pectins via electron beam irradiation and their potential prebiotic functionality. Food Hydrocoll. 2021, 113, 106551. [CrossRef]

92. Li, F.; Chen, G.; Zhang, B.; Fu, X. Current applications and new opportunities for the thermal and non-thermal processing technologies to generate berry product or extracts with high nutraceutical contents. Food Res. Int. 2017, 100, 19-30. [CrossRef]

93. Kong, Q.; Wu, A.; Qi, W.; Qi, R.; Carter, J.M.; Rasooly, R.; He, X. Effects of electron-beam irradiation on blueberries inoculated with Escherichia coli and their nutritional quality and shelf life. Postharvest Biol. Technol. 2014, 95, 28-35. [CrossRef]

94. Yoon, Y.-S.; Kim, J.-K.; Lee, K.-C.; Eun, J.-B.; Park, J.-H. Effects of electron-beam irradiation on postharvest strawberry quality. J. Food Process. Preserv. 2020, 44, e14665. [CrossRef]

95. Gómez-López, V.M.; Ragaert, P.; Debevere, J.; Devlieghere, F. Pulsed light for food decontamination: A review. Trends Food Sci. Technol. 2007, 18, 464-473. [CrossRef]

96. Santamera, A.; Escott, C.; Loira, I.; Del Fresno, J.M.; González, C.; Morata, A. Pulsed light: Challenges of a non-thermal sanitation technology in the winemaking industry. Beverages 2020, 6, 1-16. [CrossRef]

97. Gómez-López, V.M.; Pataro, G.; Tiwari, B.K.; Gozzi, M.; Meireles, M.A.A.; Shaojin, W.; Buenaventura, G.; Pan, Z.; Ramaswamy, H.S.; Sastry, S.; et al. Guidelines on reporting treatment conditions for emerging technologies in food processing. Crit. Rev. Food Sci. Nutr. 2021, 1-25. [CrossRef]

98. Escott, C.; Vaquero, C.; del Fresno, J.M.; Bañuelos, M.A.; Loira, I.; Han, S.-y.; Bi, Y.; Morata, A.; Suárez-Lepe, J.A. Pulsed Light Effect in Red Grape Quality and Fermentation. Food Bioprocess Technol. 2017, 10, 1540-1547. [CrossRef]

99. Escott, C.; López, C.; Loira, I.; González, C.; Bañuelos, M.A.; Tesfaye, W.; Suárez-Lepe, J.A.; Morata, A. Improvement of must fermentation from late harvest cv. Tempranillo grapes treated with pulsed light. Foods 2021, 10, 1416. [CrossRef]

100. Avalos-Llano, K.R.; Martín-Belloso, O.; Soliva-Fortuny, R. Effect of pulsed light treatments on quality and antioxidant properties of fresh-cut strawberries. Food Chem. 2018, 264, 393-400. [CrossRef] 